\title{
Cholidah Utama \\ Peran dan Kedudukan Ombusman Sebagai Lembaga Perlindungan Rakyat Dalam Mewujudkan Asas-Asas Umum Pemerintahan Yang Baik Peran Dan Kedudukan Ombusman Sebagai Lembaga Perlindungan Rakyat Dalam Mewujudkan Asas-Asas Umum Pemerintahan Yang Baik
}

\author{
Cholidah Utama \\ UIN Raden Fatah Palembang \\ Utamacholidah123@gmail.com
}

\begin{abstract}
Abstrak
Pencantuman Ombudsman dalam Amandemen UUD 1945 akan menempatkan keberadaan rekomendasi Ombudsman secara filosofis (sekaligus secara politis) bernilai tinggi. Sehingga meskipun tidak mengikat secara hukum tetap dipatuhi oleh Penyelenggara Negara. Kedudukan Ombudsman adalah Lembaga negara yang bersifat mandiri dan tidak memiliki hubungan organik dengan lembaga negara dan instansi pemerintahan lainnya, serta dalam menjalankan tugas dan wewenangnya bebas dari campur tangan kekuasaan lainnya.
\end{abstract}

Kata kunci : Ombusman, kedudukan, tujuan, dan Mandiri.

\section{Abstract}

The inclusion of the Ombudsman in the Amendment to the 1945 Constitution will place the existence of the Ombudsman's recommendations philosophically (as well as politically) with high value. So that even though it is not legally binding, it is still obeyed by the State Administration. The position of the Ombudsman is a state institution that is independent and does not have an organic relationship with state institutions and other government agencies, and in carrying out its duties and authority free from interference from other powers.

Keywords: Ombusman, position, destination, and Mandiri.

\section{Pendahuluan}

Istilah pengawasan dalam banyak hal sama artinya dengan kontrol. Dalam kamus umum bahasa indonesia, arti kata kontrol adalah mengawasan, pemeriksaan, mengontol adalah mengawasi, memeriksa. Fungsi Sujamto dalam Bahasa Indonesia Fungsi controlling mempunyai padanan yakni pengawasan dan pengendalian. Pengawasan ini adalah arti sempit, yang oleh Sujamto, diberi definisi sebagai segala usaha atau kegiatan untuk mengetahui dan menilai kenyataan yang sebenarnya tentang pelaksnaan tugas atau pekerjaan apakah sesuai dengan, semestinya atau tidak. Adapaun pengendalian itu pengertiannya lebih forceful daripada pengawasan, yaitu sebagai segala usaha atau jegiatan untuk menjamin dan mengarahkan agar pelaksanaan tugas atau pekerjaan berjalan sesuaia dengan semsetinya. Sedangkan Bagir Manan memandang kontrol sebagai sebuah fungsi sekaligus hak, sehingga lazim disebut dengan fungsi kontrol atau hak kontrol. Kontrol mengandung dimesni

Tersedia Online di http://jurnal.radenfatah.ac.id/index.php/medinate 


\section{Cholidah Utama \\ Peran dan Kedudukan Ombusman Sebagai Lembaga Perlindungan Rakyat Dalam \\ Mewujudkan Asas-Asas Umum Pemerintahan Yang Baik} pengawasan dan pengendalian. Pengawasan yang bertalian dengan arahan (directive), (Sirahuddin, 2012 : 125-127).

Lembaga semacam ombusman sebenarnya telah dikenal sejak lama dan telah dipraktekkan diberbagai wilayah diberbagai belahan bumi ini kurang lebih 4000 tahun yang lalu. Pada masa kerajaan Mesir mislanya raja menggunakan pegawai-pegawai yang menangani keluhan yang ditempatkan di lingkungan peradilan. Selain itu pada masa Republik Romawi, ada pula petugas yang mengawasi segala tindakan administrasi negara dan sekaligus pula menampung keluhan yang nerkaitan dengan maladministrasi. Di Asia, tepanya di Cina, raja-raja pada zaman dinasti Han dikenal dengan isitlah the Control Yuan (Sirahuddin, 2012: 139).

Menurut Pasal 1 Butir 3 undang-undang Nomor 37 Tahun 2008 “Maladministrasi adalah perilaku atau perbuatan melawan hukum, melampaui wewenang, menggunakan wewenang untuk tujuan lain dari yang menjadi tujuan wewenang tersebut, termasuk kelalaian atau pengabaian kewajiban hukum dalam penyelenggaraan pelayanan publik yang dilakukan oleh Penyelenggara Negara dan pemerintahan yang menimbulkan kerugian materiil dan/atau immateriil bagi masyarakat dan orang perseorangan."( Undang-Undang Nomor 37 Tahun 2009 Tentang Ombudsman).

Indonesia merupakan negara demokrasi yang menjunjung tinggi kedaulatan rakyat. Oleh karena itu lewat undang-undang pemerintah menjamin hak-hak dari setiap warga negaranya. Negara wajib melindungi setiap warga negara dengan memberikan perlindungan serta pelayanan yang maksimal terhadap setiap warga negara dan warga negarapun berhak memperoleh pelayanan yang adil. Setiap warga negara selalu mengharapkan pemerintahan yang bersih, jujur dan adil serta dapat menerima setiap aspirasi dari warga negaranya. Untuk mencapai pemerintahan yang bersih maka perlu di bentuk sebuah lembaga negara yang berfungsi mengawasi penyelenggaraan pemerintahan agar tidak menyalahgunakan kewenangannya secara tidak terbatas karena dalam praktek bernegara sering terjadi penyalahgunaan wewenang oleh aparatur penyelenggara negara dan pemerintahan (http://juniverganaplaw.blogspot.co.id/2014/01/kedudukan-dan-fungsi-ombudsman-

sebagai.html. diakses tanggal 2 November 2017). Oleh karena pemerintah dalam menyelenggarakan fungsinya harus berdasarkan pada asas-asas umum pemerintaham yang baik disingkat dengan AAUPB, Macam-macam AAUPB sebagai berikut :

a. Asas Kepastian Hukum (principle of legal security)

b. Asas keseimbangan (principle of proportionality)

c. Asas kesamaan dalam mengambil keputusan (principle of equality)

d. Asas bertindak cermat (principle of carefulness)

e. Asas motivasi untuk setiap keputusan (principle of motivation)

f. Asas tidak mencampuradukan kewenangan (principle of non misuse of comptence)

g. Asas permainan yang layak (principle of fair play)

h. Asas keadilan dan kewajaran (principle of reasonable or prohibition)

$i$. Asas kepercayaan dan menanggapi pengharapan yang wajar (principle of meeting raised expectation)

Tersedia Online di http://jurnal.radenfatah.ac.id/index.php/medinate 


\section{Cholidah Utama \\ Peran dan Kedudukan Ombusman Sebagai Lembaga Perlindungan Rakyat Dalam Mewujudkan Asas-Asas Umum Pemerintahan Yang Baik}

j. Asas meniadakan akibat suatu keputusan yang batal (principle of undoing the concequences of annuled decision)

k. Asas perlindungan atas pandangan atau cara hidup pribadi (principle of protection the personal may of life)

1. Asas kebijaksanaan (sapientia)

m. Asas penyelenggaraan kepentingan umum (principle of public service), (Ridwan, 2014 :224).

Keputusan Presiden Nomor 44 Tahun 2000 tentang komisi ombudsman nasional merupakan salah satu langkah untuk meningkatkan pengawasan terhadap penyelenggaraan negara serta untuk menjamin perlindungan hak-hak masyarakat. Selanjutnya Keppres ini di ubah menjadi Undang-undang yaitu Undang-undang nomor 37 Tahun 2008 tentang Ombudsman Republik Indonesia. Undang-undang ini disahkan dalam rapat paripurna DPRRI tanggal 9 September 2008.

Pasal 1 Undang-undang nomor 37 Tahun 2008 tentang Ombudsman Republik Indonesia menjelaskan bahwa : Dalam Undang-Undang ini yang dimaksud dengan:

Ombudsman Republik Indonesia yang selanjutnya disebut Ombudsman adalah lembaga negara yang mempunyai kewenangan mengawasi penyelenggaraan pelayanan publik baik yang diselenggarakan oleh penyelenggara negara dan pemerintahan termasuk yang diselenggarakan oleh Badan Usaha Milik Negara, Badan Usaha Milik Daerah,dan Badan Hukum Milik Negara serta badan swasta atau perseorangan yang diberi tugas menyelenggarakan pelayanan publik tertentu yang sebagian atau seluruh dananya bersumber dari anggaran pendapatan dan belanja negara dan/atau anggaran pendapatan dan belanja daerah. (Pasal 1 Undang-Undang Nomor 37 Tahun 2008 Tentang Ombudsman).

Maladministration is political term which describes the action of government body that can be seen as causing an injustice. Mal administrasi mencakup perilaku aparat sebagai berikut:

1. Penundaan berlarut dalam pelayanan (undue delay)

2. Penyimpangan/kesalahan dalam mengambil suatu tindakan (tidak Proporsional)

3. Penyimpangan/kesalahan dalam prosedur

4. Kesalahan menyajikan informasi/penjelasan

5. Tata kelola pencatatan/pengarsipan yang tidak memadai

6. Kesalahan dalam melakukan investigasi

7. Kesalahan dalam menanggapi persoalan

8. Komunikasi yang tidak memadai

9. Gagal/tidak memenuhi janji/komitmen, (M. Yusriza Adi S, 19).

Pengaturan mengenai ombudsman sebagai lembaga yang mengawasi penyelenggaraan pelayanan publik, sudah sangat jelas diatur dalam konstitusi Republik Indonesia. Namun meskipun demikian ombudsman atau ombudsman republik Indonesia

Tersedia Online di http://jurnal.radenfatah.ac.id/index.php/medinate 


\section{Cholidah Utama \\ Peran dan Kedudukan Ombusman Sebagai Lembaga Perlindungan Rakyat Dalam Mewujudkan Asas-Asas Umum Pemerintahan Yang Baik} merupakan lembaga negara yang tidak terdapat dalam UUD. Kelahirannya dilakukan oleh UU dalam rangka pengawasan kinerja aparatur negara dan pemerintahan serta menampung keluhan masyarakat. Lembaga yang menjalankan fungsi seperti ini belum diatur dalam UUD. Selanjutnya meskipun ombudsman sebagai lembaga pengawas sudah diatur sejak tahun 2000 dan selanjutnya menjadi undang-undang pada tahun 2008, pada kenyataannya masih banyak masyarakat yang tidak mengenal dan tidak mengetahui keberadaan lembaga pengawas ini. Masih banyak pelanggaran-pelanggaran yang dilakukan oleh penyelenggara negara dan pemerintahan dalam menjalankan tugas dan fungsinya untuk melayani masyarakat. Oleh karena itu lembaga ombudsman sangat penting untuk negara Indonesia dalam rangka mengawasi kinerja dari penyelenggara negara dan pemerintahan. Penelitian ini bertujuan untuk bagaimana pengaturan mengenai ombudsman dalam sistem hukum di Indonesia dan Apakah Kedudukan dan tujuan ombudsman sebagai lembaga perlindungan rakyat.

\section{Metodologi Penelitian}

Penelitian ini menggunakan jenis penelitian deskriptif kualitatif karena penelitian deskriptif mengamati Peran Dan Kedudukan Ombusman Sebagai Lembaga Perlindungan Rakyat Dalam Mewujudkan Asas-Asas Umum Pemerintahan Yang Baik. Penelitian deskriptif bertujuan untuk meneliti dan menemukan informasi sebanyak-banyaknya dari suatu fenomena. (M. Hariwijaya dan Triton P.B, 2011 : 22).

\section{Hasil dan Pembahasan}

\section{Pengaturan mengenai ombudsman dalam sistem hukum di Indonesia.}

Pengaruh Ombudsman masuk melalui rekomendasi yang disusun dan diberikan kepada Penyelenggaraan Negara. Walaupun rekomendasi Ombudsman tidak mengikat secara hukum, bukan berarti dapat diabaikan begitu saja. Dalam hal ini Ombudsman memiliki mekanisme pelaporan kepada DPR. Untuk kasus-kasus tertentu yang signifikan dan krusial, melalui mekanisme yang tersedia, DPR juga dapat memanggil pejabat publik (eksekutif) atas tindakan pengabaiannya terhadap eksistensi dan rekomendasi Ombudsman.

Inilah sebabnya mengapa Ombudsman menjadi sangat penting di atur dalam Amandemen UUD 1945. Rekomendasi Ombudsman yang tidak mengikat secara hukum memerlukan landasan politis yang sangat kuat. Pencantuman Ombudsman dalam Amandemen UUD 1945 akan menempatkan keberadaan rekomendasi Ombudsman secara filosofis (sekaligus secara politis) bernilai tinggi. Sehingga meskipun tidak mengikat secara hukum tetap dipatuhi oleh Penyelenggara Negara. Saat ini lebih dari lima puluh negara telah mencantumkan pengaturan Ombudsman dalam konstitusi, antara lain Denmark, Finlandia, Filipina, Thailand, Afrika Selatan, Argentina, dan Meksiko. Ombudsman Thailand yang notabene usianya lebih muda dari KON, telah terlebih dahulu mencantumkan ketentuan tentang Ombudsman dalam Konstitusi Thailand. Pengaturan Ombudsman dalam konstitusi (Amandemen UUD 1945) menjadi sangat penting bagi Anggota MPR 2004. Bagi negara yang menganut sistem presidensial seperti Indonesia, Ombudsman semestinya tidak hanya diatur dalam UU (apalagi Keputusan Presiden) tetapi sudah sepantasnya dipayungi dengan

Tersedia Online di http://jurnal.radenfatah.ac.id/index.php/medinate 
Cholidah Utama

Peran dan Kedudukan Ombusman Sebagai Lembaga Perlindungan Rakyat Dalam Mewujudkan Asas-Asas Umum Pemerintahan Yang Baik konstitusi. Di negara-negara yang menganut sistem Parlementer dan memilih bentuk Parliamentary Ombudsman, efektifitas Ombudsman juga sangat ditentukan dengan sistem check and balance yang berlaku antara legislatif dan eksekutif (http://www.hukumonline.com/berita/baca/hol11261/urgensi-pengaturan-ombudsman-dalamuud-1945, diakses tanggal 4 November 2017).

\section{Peran dan kedudukan ombudsman sebagai lembaga perlindungan rakyat.}

Lembaga ombudsman merupakan lembaga negara yang melakukan tugas pengawasan terhadap penyelenggara negara dan pemerintahan. Namun pada kenyataannya, masih banyak masyarakat yang tidak mengenal lembaga pengawas ini. Oleh karena itu sangat penting bagi masyarakat luas agar dapat mengetahui keberadaan serta kedudukan ombudsman sebagai lembaga pengawas yang secara langsung adalah sebagai lembaga yang memberi perlindungan kepada rakyat. Pemerintah juga berkewajiban untuk mensosialisasikan kepada masyarakat luas tentang keberadaan serta kedudukan dan fungsi dari lembaga ini agar secara bersama-sama masyarakat dan lembaga ombudsman berperan dalam pengawasan untuk mencapai pemerintahan yang baik, adil dan bersih (http://juniverganaplaw.blogspot.co.id/2014/01/kedudukan-dan-fungsi-ombudsmansebagai.html, diakses tanggal 2 November 2017).

Ombudsman atau ombudsman republik Indonesia merupakan lembaga negara yang tidak terdapat dalam Undang-Undang Dasar 1945. Kelahirannya dilakukan oleh Undangundang dalam rangka pengawasan kinerja aparatur negara dan pemerintahan serta menampung keluhan masyarakat. Lembaga yang menjalankan fungsi seperti ini belum diatur dalam UUD 1945. Oleh sebab itu, dalam sistem pemisahan kekuasaan, Ombudsman Republik Indonesia dapat dikatagorikan sejajar dan tidak dibawah pengaruh satu kekuasaan lain. Dengan tugas dan fungsi seperti itu, keberadaan Ombudsman Republik Indonesia sangat vital dalam pemenuhan perlindungan dan kesejahteraan masyarakat sebagai bagian tujuan bernegara.

Sehubungan dengan kedudukan ombudsman republik Indonesia seperti di atas, maka Ombudsman bukan lagi menjadi domain pemerintah seperti halnya masa berlakunya Keppres No.44 Tahun 2000. Pemerintah sudah tidak dapat lagi membentuk Ombudsman atau badan-badan dengan nama lain yang secara prinsip menjalankan tugas dan fungsi Ombudsman Republik Indonesia. Tugas mengawasi kinerja lembaga negara dan pemerintahan serta menampung keluhan masyarakat telah beralih dan dilakukan oleh lembaga negara tersendiri dan menjalankan tugas dan fungsinya secara mandiri.

Ketatanegaraan Indonesia menurut amandemen UUD 1945 juga menempatkan lembaga negara penunjangyaitu lembaga-lembaga negara yang diatur dalam konstitusi untuk membantu lembaga negara yang ditetapkan untuk menyelenggarakan fungsi negara demi terwujudnya tujuan negara. Pasal 2 UU No. 37 Tahun 2008 menegaskan bahwa kedudukan Ombudsman adalah : "Lembaga negara yang bersifat mandiri dan tidak memiliki hubungan organik dengan lembaga negara dan instansi pemerintahan lainnya, serta dalam menjalankan

Tersedia Online di http://jurnal.radenfatah.ac.id/index.php/medinate 


\section{Cholidah Utama \\ Peran dan Kedudukan Ombusman Sebagai Lembaga Perlindungan Rakyat Dalam \\ Mewujudkan Asas-Asas Umum Pemerintahan Yang Baik} tugas dan wewenangnya bebas dari campur tangan kekuasaan lainnya." (Pasal 2 UU No. 37 Tahun 2008 tentang Ombudsman ).

Berikut akan dijelaskan kedudukan ombudsman dalam menjalankan tugasnya sebagaimana yang dimuat dalam undang-undang nomor 37 tahun 2008 pasal 5, yaitu :

a. Ombudsman berkedudukan di ibu kota negara Republik Indonesia dengan wilayah kerja meliputi seluruh wilayah negara Republik Indonesia.

b. Ombudsman dapat mendirikan perwakilan Ombudsman di provinsi dan/atau kabupaten/kota.

c. Ketentuan lebih lanjut mengenai pembentukan, susunan, dan tata kerja perwakilan Ombudsman di daerah sebagaimana dimaksud pada ayat (2) diatur dengan Peraturan Pemerintah.

Ombudsman berkedudukan di ibukota negara republik Indonesia yaitu kota Jakarta, namun wilayah kerja dari ombudsman itu sendiri mencakup seluruh wilayah di Indonesia. Untuk bisa menjangkau kedaerah pelosok, serta memberikan pelayanan yang optimal maka ombudsman dapat mendirikan perwakilannya di wilayah provinsi, atau kabupaten/kota.

Pengaturan mengenai ombudsman dengan perwakilannya di daerah, lebih lanjut diatur dengan peraturan pemerintah setempat. Pengaturan Ombudsman dalam Undang-undang tidak hanya mengandung konsekuensi posisi politik kelembagaan, namun juga perluasan kewenangan dan cakupan kerja Ombudsman yang akan sampai di daerah-daerah. Dalam undang-undang ini dimungkinkan mendirikan kantor perwakilan Ombudsman di daerah Propinsi, Kabupaten/Kota. Dalam hal penanganan laporan juga terdapat perubahan yang fundamental karena Ombudsman diberi kewenangan besar dan memiliki kekuatan memaksa (subpoena power), rekomendasi yang bersifat mengikat, investigasi, serta sanksi pidana bagi yang mengahalang-halangi ombudsman dalam menangani laporan. Melalui UU No. 37 Tahun 2008, sekarang Indonesia telah memiliki Ombudsman, yang disebut Ombudsman Republik Indonesia yang telah diperkuat peran dan kedudukan. (Pasal 2 UU No. 37 Tahun 2008 tentang Ombudsman ).

Harapan terhadap peran Ombudsman RI bisa dilihat dari tujuan Ombudsman RI itu sendiri. Pasal 4 UU Nomor 37 Tahun 2008 menggariskan secara jelas mengenai tujuan Ombudsman, yakni:

1. Mewujudkan negara hukum yang demokratis, adil dan sejahtera;

2. Mendorong penyelenggaraan negara dan pemerintahan yang efektif dan efisien, jujur, terbuka, bersih, serta bebas dari korupsi, kolusi dan nepotisme;

3. Meningkatkan mutu pelayanan negara di segala bidang agar setiap warga negara dan penduduk memperoleh keadilan, rasa aman, dan kesejahteraan yang semakin baik;

4. Membantu menciptakan dan meningkatkan upaya untuk pemberantasan dan pencegahan praktik-praktik maladministrasi, diskriminasi, korupsi, kolusi serta nepotisme;

5. Meningkatkan budaya hukum nasional, kesadaran hukum masyarakat, serta supremasi hukum yang berintikan kebenaran serta keadilan (http://lo-diy.or.id/peran-ombudsmanrepublik-indonesia/, diakses tanggal 2 November 2017).

Tersedia Online di http://jurnal.radenfatah.ac.id/index.php/medinate 


\section{Cholidah Utama \\ Peran dan Kedudukan Ombusman Sebagai Lembaga Perlindungan Rakyat Dalam \\ Mewujudkan Asas-Asas Umum Pemerintahan Yang Baik}

Memperhatikan bahwa perbaikan kualitas pelayanan publik saat ini dan harapan percepatan perbaikan itu bisa dilakukan sesegera mungkin, maka UU 37 Tahun 2008 Tentang Ombudsman RI dan UU 25 Tentang Pelayanan Publik telah mengubah peran penting Ombudsman, beberapa diantaranya sebagai berikut:

1. Kalau dulu Ombudsman dikenal sebagai lembaga pemberi pengaruh (magistrature of influence) sekarang menjadi lembaga yang mampu menjatuhkan sanksi (magistrature of sanction) melalui rekomendasi yang final mengikat wajib dilaksanakan oleh penerima rekomendasi. (Ayat 1, Pasal 38, UU 37 Tahun 2008).

2. Kalau dulu, dipandang sebagai lembaga yang sekedar meneruskan laporan masyarakat, sekarang menjadi lembaga yang berwenang menghadirkan secara paksa Terlapor, Pelapor ataupun Saksi yang telah dipanggil 3 (tiga) kali berturut-turut tidak memenuhi panggilan (Pasal 31 UU 37 Tahun 2008 dan MOU antara Ombudsman Republik Indonesia dengan Kepolisian RI).

3. Sekarang Ombudsman RI tidak hanya berwenang menindaklanjuti laporan publik tetapi juga memiliki kewenangan untuk melakukan investigasi atas prakarsa sendiri. (Pasal 7, UU 37 Tahun 2008).

4. Sekarang Ombudsman RI dapat melakukan pemeriksaan ke objek pelayanan publik tanpa pemberitahuan terlebih dahulu kepada pejabat atau instansi yang dilaporkan, (Pasal 34, UU 37 Tahun 2008) dan berwenang memeriksa dokumen-dokumen terkait yang diperlukan dari instansi manapun untuk melakukan pemeriksaan laporan atau berdasarkan inisiatif investigasi sendiri (huruf b, ayat 1, pasal 8 UU 37 Tahun 2008).

5. Terdapat ancaman pidana bagi setiap orang yang menghalangi Ombudsman dalam melakukan pemeriksaan, dipidana penjara paling lama 2 (dua) tahun atau denda paling banyak Rp. 1 milyar (Pasal 44, UU 37 Tahun 2008).

6. Terdapat imunitas hukum: yaitu dalam menjalankan tugas dan wewenangnya, Ombudsman Republik Indonesia tidak dapat ditangkap, ditahan, diinterogasi, dituntut atau digugat di muka pengadilan (Pasal 10, UU 37 Tahun 2008), (http://lo-diy.or.id/peranombudsman-republik-indonesia/, diakses tanggal 2 November 2017).

\section{Kesimpulan}

1. Pengaturan ombudsman dalam sistem hukum di Indonesia.

Ombudsman tidak mengikat secara hukum, bukan berarti dapat diabaikan begitu saja. Dalam hal ini Ombudsman memiliki mekanisme pelaporan kepada DPR. Untuk kasus-kasus tertentu yang signifikan dan krusial, melalui mekanisme yang tersedia, DPR juga dapat memanggil pejabat publik (eksekutif) atas tindakan pengabaiannya terhadap eksistensi dan rekomendasi Ombudsman. Inilah sebabnya mengapa Ombudsman menjadi sangat penting di atur dalam Amandemen UUD 1945. Rekomendasi Ombudsman yang tidak mengikat secara hukum memerlukan landasan politis yang sangat kuat. Pencantuman Ombudsman dalam Amandemen UUD 1945 akan menempatkan keberadaan rekomendasi Ombudsman secara filosofis (sekaligus secara politis) bernilai tinggi. Sehingga meskipun tidak mengikat secara hukum tetap dipatuhi oleh Penyelenggara Negara.

Tersedia Online di http://jurnal.radenfatah.ac.id/index.php/medinate 


\section{Cholidah Utama \\ Peran dan Kedudukan Ombusman Sebagai Lembaga Perlindungan Rakyat Dalam Mewujudkan Asas-Asas Umum Pemerintahan Yang Baik}

2. Kedudukan dan tujuan ombudsman sebagai lembaga perlindungan rakyat.

Harapan terhadap peran Ombudsman RI bisa dilihat dari tujuan Ombudsman RI itu sendiri. Pasal 4 UU Nomor 37 Tahun 2008 menggariskan secara jelas mengenai tujuan Ombudsman, yakni:

a. Mewujudkan negara hukum yang demokratis, adil dan sejahtera;

b. Mendorong penyelenggaraan negara dan pemerintahan yang efektif dan efisien, jujur, terbuka, bersih, serta bebas dari korupsi, kolusi dan nepotisme;

c. Meningkatkan mutu pelayanan negara di segala bidang agar setiap warga negara dan penduduk memperoleh keadilan, rasa aman, dan kesejahteraan yang semakin baik;

d. Membantu menciptakan dan meningkatkan upaya untuk pemberantasan dan pencegahan praktik-praktik maladministrasi, diskriminasi, korupsi, kolusi serta nepotisme;

e. Meningkatkan budaya hukum nasional, kesadaran hukum masyarakat, serta supremasi hukum yang berintikan kebenaran serta keadilan (http://lo-diy.or.id/peran-ombudsmanrepublik-indonesia/, diakses tanggal 2 November 2017).

Kedudukan Ombudsman adalah : "Lembaga negara yang bersifat mandiri dan tidak memiliki hubungan organik dengan lembaga negara dan instansi pemerintahan lainnya, serta dalam menjalankan tugas dan wewenangnya bebas dari campur tangan kekuasaan lainnya."

\section{DAFTAR PUSTAKA}

Undang-Undang Nomor 37 Tahun 2008 tentang Ombudsman.

Undang-Undang Nomor 25 Tahun 2009 tentang Pelayanan Publik.

Agus, Reformasi Birokrasi Publik di Indonesia, Gadjah Mada University Press, Yogyakarta, 2012.

Lijan, Reformasi Pelayanan Publik ; Teori, Kebijakan, dan Implementasi, Bumi Aksara, Jakarta, 2014.

Nomenses, HAN, Jala Permata Aksara, Jakarta, 2015.

Miftah, Birokrasi dan Politik di Indonesia, PT. Raja Grafindo Persada, Jakarta, 2003

Ridwan, Hukum Administrasi N egara, Raja Grafindo Persada, Jakarta

Sirahuddin, Hukum Pelayanan publik Berbasis Partisipasi dan Keterbukaan Informasi, Setarab Press, Malang, 2012.

Siswanto, Hukum pemerintahan Daerah di Indonesia, Sinar Grafika, Jakarta, 2016

Sri, Hukum Kepegawaian di Indonesia, Sinar Grafika, Jakarta, 2014.

PERANAN OMBUDSMAN RI DALAM MEWUJUDKAN PEMERINTAHAN YANG BAIK, M. Yusriza Adi S, SH.MH, Fakultas Hukum, Universitas Medana Area, hal, 19 (Power Point)http://juniverganaplaw.blogspot.co.id/2014/01/kedudukan-danfungsi-ombudsman-sebagai.html. diakses tanggal 2 November 2017.

http://lo-diy.or.id/peran-ombudsman-republik-indonesia/, diakses tanggal 2 November 2017 .http://www.hukumonline.com/berita/baca/hol11261/urgensi-pengaturanombudsman-dalam-uud-1945, diakses tanggal 4 November 2017.

Tersedia Online di http://jurnal.radenfatah.ac.id/index.php/medinate 